Jurnal Teknik Komputer AMIK BSI

Volume 7, No.2, Juli 2021

P-ISSN 2442-2436, E-ISSN: 2550-0120

Akreditasi Ristekdikti, No: 36/E/KPT/2019 (Sinta 4)

DOI: $10.31294 /$ jtk.v4i2

\title{
Penerapan Metode Topsis Untuk Pemilihan Perumahan
}

\author{
Hari Sugiarto ${ }^{1}$
}

${ }^{1}$ Universitas Bina Sarana Informatika

1e-mail: hari.hrs@bsi.ac.id

$\begin{array}{ccc}\text { Diterima } & \text { Direvisi } & \text { Disetujui } \\ 23-02-2021 & 21-06-2021 & 28-06-2021\end{array}$

\begin{abstract}
Abstrak - Dalam menentuan perumahan baik yang harus dipilih oleh konsumen dipengaruhi oleh beberapa faktor, diantaranya harga, lokasi, fasilitas, lingkungan, dan desain rumah. Proses memilih perumahan menjadi sesuatu hal yang sangat penting agar calon pembeli tidak salah dalam mengambil keputusan dalam memilih. Dalam penelitian ini penilaian beban pemilihan perumahan dilakukan berdasarkan empat faktor utama yang digunakan sebagai acuan dalam mengambil keputusan yaitu harga, lokasi, fasilitas, desain rumah, dan lingkungan. Salah satu metode yang dapat digunakan untuk menyelesaikan permasalahan dalam pemilihan perumahan adalah metode TOPSIS (Technique for Orders Preference by Similarity to Ideal Solution) yang merupakan metode pengambilan keputusan multikriteria yang menerapkan prinsip bahwa alternatif yang terpilih harus mempunyai jarak terdekat dengan solusi ideal positif dan jarak terjauh dengan solusi ideal negatif. Dengan metode ini konsumen dapat menentukan pilihan atau mengambil sebuah keputusan dengan cara menentukan nilai bobot untuk setiap atribut, kemudian dilanjutkan dengan proses perankingan yang akan memberikan alternatif terbaik dari sejumlah alternatif, alternatif yang memiliki nilai bobot tertinggi adalah alternatif pilihan yang memiliki nilai prioritas tertinggi. Berdasarkan metode ini akan didapatkan hasil peringkat atau (rank) yang nantinya digunakan sebagai acuan dalam menentukan pengambilan keputusan. Hasil dari proses perhitungan metode TOPSIS adalah berupa informasi pemilihan perumahan yang paling mendekati pilihan yang diinginkan konsumen yang ingin memiliki rumah ideal.
\end{abstract}

Kata kunci : Perumahan, bobot penilaian, topsis

Abstract - Determining which housing to choose by consumers is influenced by many factors, including price, location, facilities, environment, and house design. The housing selection process is very important so that prospective buyers do not make the wrong choice. In this study, an assessment of housing selection load was carried out based on four main factors used as a reference in decision making, namely price, location, facilities, house design, and environment. One method that can be used to solve problems in housing selection is the TOPSIS (Technique for Orders Preference by Similarity to Ideal Solution) method which is a multi-criteria decision-making method that applies the principle that the chosen alternative must have the closest distance to the ideal positive solution and the farthest distance. with a negative ideal solution. With this method consumers can make choices or make a decision by determining the weight value for each attribute, then proceed with a ranking process that will provide the best alternative from a number of alternatives, the alternative that has the highest weight value is the alternative option that has the highest priority value. Based on this method, the ranking results will be obtained which will be used as a reference in determining decision making. The result of the calculation process of the TOPSIS method is in the form of housing selection information that is closest to the choice desired by consumers who want to have an ideal home.

Keywords: housing, assessment weight, topsis

\section{PENDAHULUAN}

Setelah melalui krisis yang melanda Indonesia sejak tahun 1998, dunia properti kembali hadir sesudah terpuruk karena krisis moneter. Bidang usaha dibidang properti mulai tumbuh kembali, baik dalam jumlah kecil, menengah maupun besar. Cara pengembangan ini tidak hanya terjadi di daerah- daerah tertentu, tetapi juga hampir diseluruh daerah perkotaan. Luapan perkembangan dibidang properti ini tidak hanya dipengaruhi oleh mulai pulihnya perekonomian, akan tetapi juga minat para konsumen mengikuti perkembangan ini. Semakin meningkatnya jumlah konsumen dari tahun ke tahun. Kelompok yang mengembangkan properti banyak 
yang menawarkan pilihan dari mulai harga, lokasi, desain, serta lingkungan dan yang lainnya. Perkembangan lokasi perumahan mempunyai andil usaha yang besar dalam perkembangan kota. Permintaan tempat tinggal akan selalu meningkat dari tahun ke tahun. Didalam proses pembangunan perumahan perlu ditingkatkan dan dikembangkan baik secara terpadu dan terarah, terencana dan berkelanjutan. Namun pada pelaksanaanya, pengembang perlu memikirkan dengan baik untuk menentukan berbagai sudut pandang sehingga menjadi satu kesatuan dilihat dari segi fungsi, wujud tata ruang fisik, kehidupan ekonomi dan sosial budaya untuk menanggung dan menjamin kelestarian lingkungan hidup dan menaikkan kualitas kehidupan manusia dalam berkeluarga dan bermasyarakat. Dalam keadaan demikian, banyak yang akan datang dari daerah sekitar maupun dari luar daerah ke kota Cikarang dengan maksud akan bekerja, berdagang, sekolah dan lain-lain. Hal ini disatu sisi menimbulkan sesuatu yang harus diselesaikan yaitu hunian bagi masyarakat namun disisi lain merupakan peluang bagi kalangan pengembang properti untuk menyediakan sarana hunian dengan membangun perumahan-perumahan yang dibutuhkan. Konsumen harus pandai memilih perumahan mana yang akan diambil sesuai dengan kriteria yang konsumen inginkan, setelah melihat kejadian tersebut, karena menurut Undang-undang Republik Indonesia Nomor 4 Tahun 1992 tentang Perumahan dan Permukiman BAB III Pasal 5 dijelaskan bahwa "Setiap warga negara mempunyai hak untuk menempati dan/atau menikmati dan/atau memiliki rumah yang layak dalam lingkungan yang sehat, aman, serasi, dan teratur" (DPR RI, 1992).

Hasil yang diberikan oleh sistem pendukung keputusan dapat memberikan suatu alternatif pemecahan masalah yang ada, sehingga konsumen dapat mengambil keputusan yang dibuat menjadi lebih baik. Metode yang dipakai dalam pengambilan keputusan pemilihan lokasi pendirian grosir pulsa ini adalah Technique for Order Preference by Similarity to Ideal Solution (TOPSIS). Hal ini dikarenakan metode TOPSIS mampu melakukan perangkingan terhadap alternatif terpilih. Dimana alternatif terpilih yang terbaik tidak hanya memiliki jarak terpendek dari solusi ideal positif, tetapi juga memiliki jarak terpanjang dari solusi ideal negatif. Solusi ideal positif diartikan solusi yang memaksimalkan atribut keuntungan (profit) dan meminimalkan atribut biaya $(\operatorname{cost})$, sedangkan solusi ideal negatif diartikan dengan solusi yang meminimalkan atribut keuntungan(profit) dan memaksimalkan biaya (cost).

\section{METODOLOGI PENELITIAN}

Teknik pengumpulan data yang penulis lakukan untuk menunjang tahapan penelitian kajian tentang Penerapan Metode Topsis Untuk Pemilihan Perumahan dijelaskan secara umum sebagai berikut : a. Wawancara (Interview): Penulis melakukan wawancara kepada beberapa konsumen perumahan yang dilakukan dengan tatap muka dan tanya jawab langsung melalui penyebaran kuisioner.

b. Observasi (Observation): Penulis melakukan observasi secara langsung ke beberapa marketing perumahan untuk mendapatkan informasiinformasi terkait dengan desain rumah, fasilitas, harga, lingkungan dan lain-lain.

c. Studi Pustaka (Library Research): Penulis melakukan tinjauan pustaka dengan cara mengumpulkan beberapa referensi melalui beberapa sumber seperti buku, jurnal ilmiah dan ebook yang mengacu pada metode TOPSIS.

Menurut Hidayat dalam (Nurelasari \& Purwaningsih, 2020) Metode Penelitian adalah langkah yang dimiliki dan dilakukan oleh peneliti dalam rangka untuk mengumpulkan informasi atau data serta melakukan investigasi pada data yang telah didapatkan tersebut. Metode yang dipakai dalam pengambilan keputusan pemilihan lokasi pendirian grosir pulsa ini adalah Technique for Order Preference by Similarity to Ideal Solution (TOPSIS). Menurut Ridaini dalam (Kristiana, 2018) "TOPSIS menggunakan prinsip bahwa alternatif yang terpilih harus mempunyai jarak terdekat dari solusi ideal positif dan terjauh dari solusi ideal negatif dari sudut pandang geometris dengan menggunakan jarak Euclidean untuk menentukan kedekatan relatif dari suatu alternatif dengan solusi ideal. Metode yang digunakan dalam penelitian ini adalah TOPSIS meskipun dengan alur algoritma yang sederhana tetapi dapat menjadi bahan solusi terhadap permasalahan dalam menentukan objek lokasi”.

Menurut Nofriansyah dalam (Sunarti, 2018), tahapan

- tahapan dalam metode TOPSIS yaitu:

a. membuat matriks keputusan yang ternormalisasi

b. membuat matriks keputusan yang ternormalisasi tebobot

c. menentukan matriks solusi ideal positif dan matriks solusi ideal negatif

d. menentukan jarak antara nilai setiap alternatif dangan matriks solusi ideal positif dan matriks solusi ideal negatif

e. menentukan nilai preferensi untuk setiap alternative.

Sedangkan langkah - langkah untuk menyelesaikan permasalahan menggunakan metode TOPSIS:

1) Membuat matriks keputusan yang ternormalisasi.Metode TOPSIS membutuhkan rating kinerja setiap alternatif $\mathrm{Ai}$ pada setiap kriteria Ci yang ternormalisasi. 


$$
r i j=\frac{\text { xij }}{\sqrt{\sum_{i=1}^{m} \times \frac{2}{i j}}}
$$

Keterangan:

$$
\begin{aligned}
& \mathrm{i}=1,2, \ldots ., \mathrm{m} ; \mathrm{dan} \mathrm{j}=1,2, \ldots, \mathrm{n} . \\
& \text { rij }=\text { matriks keputusan ternormalisasi } \\
& \text { xij = bobot kriteria ke } \mathrm{j} \text { pada alternatif ke } \mathrm{i} \\
& \mathrm{i}=\text { alternatif ke } \mathrm{i} \\
& \mathrm{j}=\text { kriteria ke } \mathrm{j}
\end{aligned}
$$

2) Membuat matriks keputusan yang ternormalisasi terbobot

$$
\left[\begin{array}{lll}
y 11 & y 21 & y i j \\
y 21 & y 22 & y i j \\
y 31 & y 31 & y i j
\end{array}\right]
$$

Keterangan:

$\mathrm{Wj}$ adalah bobot kriteria ke-j

Yij adalah elemen dari matriks keputusan yang ternormalisasi

3) Menentukan matriks solusi ideal positif dan matriks solusi ideal negatif

$$
\mathrm{A}^{+}=\left(\mathrm{y} 1^{+}, \mathrm{y}^{+}, \mathrm{yi}^{+}\right)
$$$$
\mathrm{A}^{-}=\left(\mathrm{y} 1^{-}, \mathrm{y}^{-}, \mathrm{yi}^{-}\right)
$$

\section{Keterangan:}

$$
\begin{aligned}
& \mathrm{j} \mathrm{y}^{+}=\max \text { yij, jika } \mathrm{j} \text { adalah atribut } \\
& \text { keuntungan min yij, jika } \mathrm{j} \text { adalah atribut } \\
& \text { biaya } \\
& \mathrm{j} \mathrm{y}^{-}=\min \text { yij, jika j adalah atribut } \\
& \text { keuntungan max yij, jika j adalah atribut } \\
& \text { biaya }
\end{aligned}
$$

4) Menentukan jarak antara nilai setiap alternatif dengan matriks solusi ideal positif $\left(\mathrm{D}^{+}\right)$dan $\left(\mathrm{D}^{-}\right)$ matriks solusi ideal negative

$$
\begin{aligned}
& D^{+}=\sqrt{\sum_{i=1}^{m} \sum_{i=1}^{m}\left(y i^{2}-y i j^{+}\right)^{2}} \\
& D^{-}=\sqrt{\sum_{i=1}^{m}\left(y i^{2}-y i j^{-}\right)^{2}} \ldots \ldots .
\end{aligned}
$$

\section{Keterangan:}

j $\mathrm{y}^{+}$adalah elemen dari matriks solusi ideal positif

j $\mathrm{y}^{-}$adalah elemen dari matriks solusi ideal negative

5) Menentukan nilai preferensi untuk setiap alternatif. Nilai preferensi merupakan kedekatan suatu alternatif terhadap solusi ideal

$$
\mathrm{Vi}=\frac{D_{i}^{-}}{D_{i}^{-}+D_{i}^{+}}
$$

Dimana:

Nilai Vi yang lebih besar menunjukkan prioritas alternatif menurut Turban dalam (Setiawan, 2019).

\section{HASIL DAN PEMBAHASAN}

Dalam proses hasil dan pembahasan ini dijelaskan secara umum bagaimana cara melakukan penghitungan perbandingan konsistensi kriteria penilaian dan perbandingan konsistensi wilayah perumahan terhadap kriteria yang dinilai dengan menggunakan metode TOPSIS secara keseluruhan. Dari beberapa wilayah perumahan yang telah ditentukan, pihak terkait dapat menggunakan metode TOPSIS sebagai pendukung keputusan untuk menentukan wilayah perumahan yang tepat. Adapun hasil perhitungan dengan menggunakan metode TOPSIS dan telah dilakukan penulis adalah sebagai berikut :

\section{Menentukan Kriteria yang akan dipertimbangkan}

Tabel 1. Tabel Kriteria

\begin{tabular}{ll}
\hline \multicolumn{1}{c}{ Kode } & \multicolumn{1}{c}{ Kriteria } \\
\hline C1 & Harga \\
C2 & Lokasi \\
C3 & Fasilitas \\
C4 & Lingkungan \\
C5 & Desain Rumah \\
\hline
\end{tabular}

Sumber: Hasil Penelitian (2021)

Dalam penelitian ini, penulis mengambil 5 (lima) perumahan didaerah Cikarang yang cukup terkenal yang dijadikan sebagai pilihan dalam proses pemilihan perumahan antara lain:

Tabel 2. Tabel Alternatif

\begin{tabular}{ll}
\hline \multicolumn{1}{c}{ Kode } & \multicolumn{1}{c}{ Alternatif } \\
\hline A1 & Gramapuri Persada \\
A2 & Kota Serang Baru \\
A3 & Mega Regency \\
\hline
\end{tabular}

Sumber: Hasil Penelitian (2021)

\section{Menentukan bobot preferensi untuk setiap kriteria}

Setelah menentukan kriteria penilaian, lalu menentukan nilai bobot preferensi dari tiap-tiap kriteria berdasarkan tingkat kepentingan antara kriteria yang satu dengan kriteria yang lainnya. Nilai perbandingan tingkat kepentingan antara kriteria yang satu dengan kriteria yang lainnya dapat dinyatakan dengan pernyataan sebagai berikut:

1. Sangat Rendah $=1$

2. Rendah $=2$

3. Cukup $=3$

4. Tinggi $=4$

5. Sangat Tinggi $=5$

Dari pernyataan diatas, maka dapat disimpulkan bahwa nilai preferensi terdiri dari bilangan dari 1 sampai 5 , semakin tinggi nilai preferensi suatu kriteria, maka semakin tinggi nilai preferensi suatu kriteria, maka semakin tinggi tingkat kepentingan kriteria tersebut dalam menarik 
sebuah keputusan. Nilai preferensi dari tiap-tiap kriteriaa ditentukan sebagai berikut:

Table 3. Tabel bobot dan kriteria

\begin{tabular}{lll}
\hline \multicolumn{1}{c}{ Kode } & \multicolumn{1}{c}{ Kriteria } & Bobot \\
\hline C1 & Harga & 5 \\
C2 & Lokasi & 4 \\
C3 & Fasilitas & 3 \\
C4 & Lingkungan & 4 \\
C5 & Desain Rumah & 3 \\
\hline
\end{tabular}

Sumber: Hasil Penelitian (2021)

3. Membentuk matriks keputusan berdasarkan nilai preferensi setiap kriteria terhadap semua alternatif :

Table 4. matriks Keputusan

\begin{tabular}{llllll}
\hline Kode & C1 & C2 & C3 & C4 & C5 \\
\hline A1 & 5 & 5 & 4 & 3 & 4 \\
A2 & 3 & 5 & 3 & 4 & 5 \\
A3 & 3 & 3 & 3 & 5 & 4 \\
\hline
\end{tabular}

Sumber: Hasil Penelitian (2021)

Setelah membentuk matriks keputusan, langkah selanjutnya adalah menormalisasikan nilai matriks keputusan sebagai berikut :

$$
\begin{aligned}
& \mathrm{X} 1 \quad=\sqrt{5^{2}+3^{2}+3^{2}}=6.557 \\
& r_{11}=\frac{5}{6.557}=0.762 \\
& r_{21}=\frac{3}{6.557}=0.457 \\
& r_{21}=\frac{3}{6.557}=0.762 \\
& \mathrm{X} 2 \quad=\sqrt{5^{2}+5^{2}+3^{2}}=7.681 \\
& r_{12}=\frac{5}{7.691}=0.650 \\
& r_{22}=\frac{5}{7.681}=0.650 \\
& r_{22}=\frac{a}{7.691}=0.390
\end{aligned}
$$

$$
\begin{gathered}
=\sqrt{4^{2}+3^{2}+3^{2}}=5.830 \\
r_{13}=\frac{4}{5.830}=0.686 \\
r_{2 a}=\frac{a}{5.830}=0.514 \\
r_{2 a}=\frac{3}{5.930}=0.514
\end{gathered}
$$

$\mathrm{X} 4=\sqrt{3^{2}+4^{2}+5^{2}}=7.071$

$$
\begin{aligned}
& r_{14}=\frac{a}{7.071}=0.424 \\
& r_{24}=\frac{4}{7.071}=0.565 \\
& r_{24}=\frac{5}{7.071}=0.707
\end{aligned}
$$

X5

$$
\begin{gathered}
=\sqrt{4^{2}+5^{2}+4^{2}}=7.549 \\
r_{15}=\frac{4}{7.549}=0.529 \\
r_{25}=\frac{5}{7.549}=0.662 \\
r_{35}=\frac{4}{7.549}=0.529
\end{gathered}
$$

Sehingga diperoleh nilai (R) sebagai berikut:

$$
R=\left(\begin{array}{lllll}
0.762 & 0.650 & 0.686 & 0.424 & 0.529 \\
0.457 & 0.650 & 0.514 & 0.565 & 0.662 \\
0.762 & 0.390 & 0.514 & 0.707 & 0.529
\end{array}\right)
$$

4. Setelah memperoleh matriks ternormalisasi, selanjutnya nilai pada matriks normalisasi dikalikan dengan nilai preferensi pada setiap kriteria:

$$
\begin{aligned}
& y_{11}=w_{1} x r_{11}=5 \times 0.762=3.81 \\
& y_{21}=w_{1} x r_{21}=5 \times 0.457= \\
& 2.285 \\
& y_{\mathrm{aI}}=w_{1} \times r_{\mathrm{aI}}=5 \times 0.762=3.81 \\
& y_{12}=w_{2} \quad x r_{12}=4 \times 0.650=2.6 \\
& y_{22}=w_{2} x r_{22}=4 \times 0.650=2.6 \\
& y_{b_{2}}=w_{2} x r_{a 2}=4 x 0.390=1.56 \\
& y_{13}=w_{3} x r_{13}=3 \times 0.686= \\
& 2.058 \\
& y_{2 a}=w_{a} x r_{2 a}=3 \times 0.514= \\
& 1.542 \\
& y_{\text {ba }}=w_{a} x r_{3 a}=3 \times 0.514= \\
& 1.542 \\
& y_{14}=w_{4} x r_{14}=4 \times 0.424= \\
& 1.696 \\
& y_{24}=w_{4} \times r_{24}=4 \times 0.565=2.26 \\
& y_{34}=w_{4} \times r_{34}=4 \times 0.707= \\
& 2.828 \\
& y_{15}=w_{5} \times r_{15}=3 \times 0.529= \\
& 1.587 \\
& y_{25}=w_{5} \times r_{25}=3 \times 0.662= \\
& 1.986 \\
& y_{25}=w_{5} \times r_{25}=3 \times 0.529= \\
& 1.587
\end{aligned}
$$

Sehingga diperoleh matriks Y :

$$
Y=\left(\begin{array}{ccccc}
3.81 & 2.6 & 2.058 & 1.696 & 1.587 \\
2.285 & 2.6 & 1.542 & 2.26 & 1.986 \\
3.81 & 1.56 & 1.542 & 2.828 & 1.587
\end{array}\right)
$$

5. Menentukan matriks ideal positif $A^{+}$dan matriks ideal negatif $\boldsymbol{A}^{-}$

a. Menentukan matriks ideal positif $A^{+}$: $Y_{1}^{+}=\max \{3.81 ; 2.285 ; 3.81\}=3.81$ 
$Y_{2}^{+}=\max \{2.6 ; 2.6 ; 1.56\}=2.6$

$Y_{3}^{+}=\max \{2.058 ; 1.542 ; 1.542\}=2.058$

$Y_{4}^{+}=\max \{1.696 ; 2.26 ; 2.828\}=2.828$

$Y_{5}^{+}=\max \{1.587: 1.986 ; 1.587\}=1.986$

b. Menentukan matriks ideal negatif $A^{-}$:

$Y_{1}^{-}=\min \{3.81 ; 2.285 ; 3.81\}=2.285$

$Y_{2}^{-}=\min \{2.6 ; 2.6 ; 1.56\}=1.56$

$Y_{a}^{-}=\min \{2.058 ; 1.542 ; 1.542\}=1.542$

$Y_{4}^{-}=\min \{1.696 ; 2.26 ; 2.828\}=1.696$

$Y_{5}^{-}=\min \{1.587 ; 1.986 ; 1.587\}=1.587$

6. Menentukan jarak antara nilai terbobot setiap alternatif terhadap solusi ideal positif :

$$
\begin{aligned}
& g=
\end{aligned}
$$

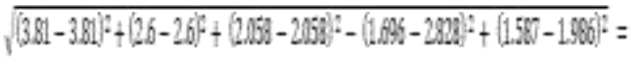

$$
\begin{aligned}
& \text { Bat? } \\
& \text { of }=
\end{aligned}
$$

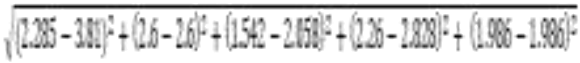

$$
\begin{aligned}
& =1.707 \\
& \mathrm{gt}=
\end{aligned}
$$

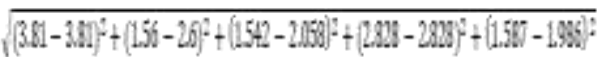

$$
\begin{aligned}
& =1.227
\end{aligned}
$$

7. Menentukan jarak antara nilai terbobot setiap alternatif terhadap solusi ideal negatif :

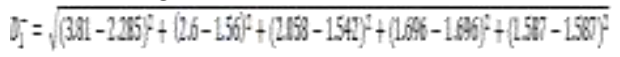
$=1916$

$$
D_{0}=
$$$$
\sqrt{\left.(235-225)^{2}+(26-156)^{2}+[154-1.541)^{2}+(2 X)-1656\right)}+
$$$$
[1,966-1508]^{3}=1.49
$$

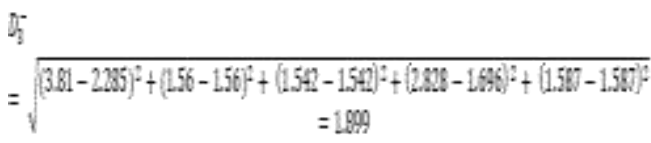

8. Menentukan nilai preferensi untuk setiap alternative $(\mathrm{Vi})$

$$
\begin{aligned}
& V 1=\frac{1.916}{0.399+1.916}=1.585 \\
& V 2=\frac{1.249^{1.21 .249}}{1.707+1.248}=0.422 \\
& V 3=\frac{1.899}{1.227+1.899}=0.607
\end{aligned}
$$

Tabel 5. Tabel Nilai Vi

\begin{tabular}{lll}
\hline alternatif & Hasil & Rangking \\
\hline A1 & 1.585 & 1 \\
A2 & 0.422 & 3 \\
A3 & 0.607 & 2 \\
\hline
\end{tabular}

umber: Hasil Penelitian (2021)

Dari hasil perhitungan secara manual diatas, alternatif dengan kode A1 yaitu Gramapuri Persada memiliki nilai preferensi tertinggi dengan nilai preferensi 1.585, lebih tinggi dibandingkan dengan alternatif A2 dengan nilai 0,422 dan alternatif A3 dengan nilai 0,607. Sehingga Perumahan Gramapuri Persada adalah pilihan pertama yang paling cocok dengan keinginan konsumen, meliputi harga yang terjangkau, lokasi, fasilitas, lingkungan, dan desain rumah.

\section{KESIMPULAN}

Kesimpulan yang dapat dijabarkan adalah sebagai berikut:

a. Dengan metode TOPSIS dapat membantu pihak terkait dalam pengambilan keputusan dengan beberapa alternatif yang sesuai dengan kriteria yang ada.

b. Dengan metode TOPSIS dapat dihasilkan rekomendasi kepada konsumen agar dapat memilih perumahan terbaik dan hasil rekomendasi telah disesuaikan dengan kebutuhan berdasarkan keinginan yang dibutuhkan.

Hasil analisis dari perhitungan metode TOPSIS menyatakan bahwa alternatif yang terpilih dan paling sesuai dengan kriteria yang diinginkan oleh konsumen adalah perumahan Gramapuri Persada, karena perumahan tersebut mempunyai nilai tertinggi dari 5 (lima) aspek kriteria yang ditentukan, antara lain: Lokasi, fasilitas, lingkungan, dan desain rumah.

\section{REFERENSI}

DPR RI. (1992). UNDANG-UNDANG TENTANG PERUMAHAN DAN PERMUKIMAN

Kristiana, T. (2018). Sistem Pendukung Keputusan Dengan Menggunakan Metode TOPSIS Untuk Pemilihan Lokasi Pendirian Grosir Pulsa. Jurnal Paradigma, XX(1), 8-12.

Nurelasari, E., \& Purwaningsih, E. (2020). Sistem Pendukung Keputusan Pemilihan Perumahan Terbaik dengan Metode TOPSIS. JUSTIN (Jurnal Sistem Dan Teknologi Informasi), 08(4), 317-321. https://doi.org/10.26418/justin.v8i4.41036

Setiawan, A. (2019). PENGAMBILAN KEPUTUSAN UNTUK MENYELEKSI PENERIMAAN GURU MATEMATIKA DENGAN METHODE TOPSIS. Jurnal Manajemen Informatika \& Komputerisasi Akuntansi, 3(1), 14-20.

Sunarti. (2018). Perbandingan Metode TOPSIS dan SAW Untuk Pemilihan Rumah Tinggal. Journal of Information System, 3(1), 69-79. 